\title{
Likelihood of confusion: what is the yardstick? Trade mark jurisprudence in Tanzania
}

\author{
Alex B. Makulilo*
}

\section{The basic issue}

In the recent past, trade mark litigation has gradually increased in the High Court of Tanzania (HCT). ${ }^{1}$ This litigation includes disputes over registration of trade marks, applications for temporary injunctions, trade mark infringement, and passing-off. ${ }^{2}$ Although I have classified trade mark litigation into four distinct groups, more often they tend to overlap in practice. The analysis in this article is limited to case law on trade mark infringement because it raises the most critical legal issues.

The basic legal issue in an action for trade mark infringement is whether a commercial use of a proprietor's trade mark by a competitor is likely to confuse consumers. In considering this legal issue, courts in different jurisdictions (eg Kenya, Uganda, Nigeria, South Africa, USA, and the UK) apply the likelihood of confusion test. ${ }^{3}$ As we shall see, the HCT has rarely considered this test in its judgments. In one relatively consistent test, the court has looked at similarity in trade marks to determine infringement that suggests that the test provides a high level of protection for brand owners. However, this test has an adverse consequence for competition in the markets as it creates an unnecessary monopoly for brand owners. Because of this, defendant companies have always been ordered to pay to huge damages and faced injunctions against use of trade marks in dispute which might have not been the case if the likelihood of confusion test was applied. Admittedly, while similarity is one of the factors which courts have to consider in determining confusion, similarity as such is far from determinative.

\footnotetext{
Email: alex.makulilo@out.ac.tz.

1 According to my search from the Civil Case Register at the HCT, Dar es Salaam District Registry and Commercial Court Division, at Dar es Salaam, as well as the Civil Appeal Register at the Court of Appeal of Tanzania, it is estimated that between 1980 and 2011, some 21 trade mark cases were decided. Trade mark cases are less common in other HCT Registries such as Arusha, Dodoma, Tabora, Mbeya, and Mwanza, probably because most businesses have their headquarters in Dar es Salaam and suits are instituted where the defendant resides (or is headquartered), or where a cause of action arose-quite often Dar es Salaam, where the Trade mark Office is.

2 See eg Kouk Oil and Grains PTE Ltd v Murzah Oil Mill Ltd, Misc. Civil Reference No 14 of 2002, HCT (Commercial Division), Dar es Salaam
}

\section{The author}

- Alex B. Makulilo is an advocate of the High Court of Tanzania, lecturer at the Open University of Tanzania, and $\mathrm{PhD}$ student, University of Bremen.

\section{This article}

- The most frequent issue which arises in any case of trade mark infringement is whether a commercial use of a particular trade mark is likely to confuse consumers.

- In this article, the author examines case law on trade mark infringement developed by the High Court of Tanzania and argues that this case law currently falls short of providing prescriptory guidance in terms of ambit and criteria for determining likelihood of confusion.

\section{Defining trade mark infringement}

The Trade and Service Marks $\mathrm{Act}^{4}$ (TMA) does not define the term trade mark infringement. An attempt by HCT to define it in Colgate-Palmolive Company has not provided sufficient guidance. In that case, the court merely reproduced the wording of section 32 of the TMA without any further analysis. Likewise, scholars have found difficult to define trade mark infringement. Phillips, for example, defines trade mark infringement in terms of unauthorized uses. ${ }^{5}$ Re-stating the grounds for trade mark infringement under European law,

(Unreported), Colgate-Palmolive Company v Zakaria Provision Stores, Royalex, Al Zameer Enterprises and P\& D Agrimech Ltd, civil Case No 1 of 1997, HCT, Dar es Salaam (unreported); and Agro-Processing and Allied Products Limited $v$ Said Salim Bhakresa \& Co. Limited and Registrar of Trade and Services Marks, Commercial Case No 31 of 2004, HCT (Commercial Division), Dar es Salaam (unreported).

3 Likelihood of confusion is the legal standard for assessing whether a competitor's trade mark infringes a proprietor's trade mark. The application of this test is limited to registered trade marks in this article.

4 Cap, 326 RE 2002.

5 J Phillips, Trade Mark Law: A Practical Anatomy (Oxford University Press 2003) $\$ 7.03$. 
Phillips explains that trade mark infringement occurs where identical trade mark is used upon goods or services which are the same as those for which the trade mark is registered. Infringement may also occur where an identical mark is used for similar goods or services, a similar mark for the same goods or services, or a similar mark for similar goods or services, where in each case there exists a likelihood of confusion on the part of consumers. Also, infringement occurs where there is a use of an identical or similar trade mark on goods or services which are quite different from those for which the trade mark is registered. Finally, infringement may occur in well-known trade marks when used to represent a connection between the user and trade mark owner which damages the proprietor's interest. It can be submitted that the grounds on which trade mark infringement under EU law is based are all covered in section 32 of TMA, making European case law persuasive authority for the Tanzanian courts.

\section{Legal standards for protection of registered trade marks}

Registered trade marks are protected against infringement by sections 31 and 32 of the TMA. Section 31 vests exclusive rights in the proprietor of a registered trade mark, while section 32 of TMA protects such exclusive rights against infringement.

\section{Section 31 of the TMA}

Section 31 of the TMA grants an exclusive right to the proprietor to use or authorize others to use such trade marks in relation to goods or services. This exclusive right accrues only when a proprietor has fulfilled the requirements of sections 16-20 of the TMA which relate to registration requirements. The most important of these requirements is that a trade mark can only be registered if it is distinctive.

The exclusive right referred to in section 31 is not absolute, being subject to other provisions of TMA and limitations or conditions entered in the register of trade marks. Examples of such limitations and conditions include fair use under section 34(b) of TMA. Besides fair use, a proprietor of trade mark may also assign, transmit, or license their trade mark to third parties. In each of these cases, the proprietor's exclusive right becomes divisible.

6 See Verimark (Pty) Ltd v BMW AG [2007] SCA 53 (RSA) p 5, which, being a foreign judgment in Tanzania, provides a persuasive interpretation of $s 31$ of TMA.
Apart from those express limitations and conditions provided in TMA, the exclusive right in section 31 of TMA is also limited to the general function and purpose of trade marks: protecting a trade mark as a badge of origin. Consequently, the exclusive right in TMA is not supposed to be interpreted so widely to give greater protection to proprietors of trade marks than that which is necessary for attaining the purpose of trade mark registration. ${ }^{6}$ This is because registration of a mark creates only a presumption that it is legitimate and eligible for protection under $\mathrm{TMA}^{7}$ and nothing more.

\section{Section 32 of the TMA}

Section 32 protects the exclusive right granted in section 31 against infringements. It essentially prohibits someone who is not a proprietor of a trade mark or its registered user from using a mark which is identical or which resembles the proprietor's trade mark for good or services which are closely related. The logic behind this prohibition is to protect consumers against likelihood of confusion to identity of goods or services in the market and at the same time protect the distinctive character or acquired reputation of the trade mark. Its text reads, in full, as follows:

The exclusive right referred to section 31 shall be deemed to be infringed by any person who, not being the proprietor of a trade mark or its registered user using it by way of the permitted use, uses a sign either:

(a) identical with or so nearly resembling it as to be likely to deceive or cause confusion, in the course of trade or business, in relation to any goods in respect of which it is registered or in relation to any closely related goods and in such manner as to render the use of the sign likely to be either:

(i) as being used as a trade mark or business or company name; or

(ii) in case in which the use is upon the goods or in physical relation to them, or in relation to services, or in an advertising circular or other advertisement issued to the public, as importing a reference to some person having the right either as proprietor or as a registered user to use the trade marks or to goods or services with that person is connected in the course of business or trade; or

7 Under s 50(1) of the TMA, a valid registration is deemed 'prima facie' evidence of the 'ownership' prong of the infringement test; this presumption can also be found in Art 16(1) of the Agreement on TradeRelated Aspects of Intellectual Property Rights (TRIPS), 1994. 
(b) identical with or nearly resembling it in the course of trade or business in any manner likely to impair the distinctive character or acquired reputation of the trade mark.

From section 32 of the TMA, a trade mark infringement may exist where a plaintiff successfully establishes three elements cumulatively. First, a plaintiff must establish that the defendant's trade mark is either identical or similar to his or her trade mark. Second, he or she must establish that the defendant's goods or services upon which the trade mark has been applied is either identical or similar. Finally, a plaintiff must establish if such use of the defendant's similar or identical trade mark to the said goods or services is likely to cause confusion to consumers as to the choice of the products they intended to purchase. In practice, if trade marks are identical and have been used in relation to identical goods or services, likelihood of confusion is always presumed. The rationale for this is that it is natural for human beings to confuse identical objects, images, etc.

Having set out the legal provisions which protect trade marks against infringement, we now examine the jurisprudence of the High Court of Tanzania.

\section{HCT jurisprudence on trade mark infringement}

\section{Identical or similar trade marks}

\section{Legal issues}

A close analysis of HCT case law reveals that the court has persistently framed legal issues incorrectly in determining identity or similarity between trade marks. In Colgate Palmolive, the court framed an issue whether the mark and getup used for ABC Dent toothpaste was identical, or confusingly similar to that used for Colgate toothpaste. ${ }^{8}$ The catch words from this issue are identical and confusingly similar. Surprisingly, the court abandoned discussion of these basic legal concepts. Instead, it proceeded to discuss a different issue: whether the two trade marks were similar. It is arguable that the terminologies of identical and confusingly similar neither individually nor collectively mean

8 n 2, above, p 3 .

9 LTJ Diffusion SA v Vertbaudet SA, C-291/00, European Court of Justice.

10 The terms 'confusingly similar' and 'likelihood of confusion' both refer to the standard required to prove infringement of a trade mark, http:// marklaw.com/trade mark-glossary/confuse.htm (accessed on 20 November 2010). similarity. A mark may only be considered to be identical to another if it reproduces, without any modification or addition, all the elements constituting the trade mark or where, viewed as a whole, it contains differences so insignificant that they may go unnoticed by the average consumer. ${ }^{9}$ At the same time, the term confusingly similar can never refer to similarity as such but to the legal standard required to prove infringement, ie likelihood of confusion. ${ }^{10}$

Although it is settled law that, where a court frames an incorrect issue but the judgment gives a correct finding, such an irregularity does not result in an illegality, ${ }^{11}$ it is still arguable that where technical terms are involved in framing issues it is unlikely that the court will arrive at a correct finding. This view can well be supported by the court's finding in Colgate Palmolive where the totality of evidence adduced by the plaintiff clearly established that there were striking similarities in the two getups. Having found that, the court concluded that the criteria of being identical or confusingly similar were affirmatively answered. However, on a closer analysis, the court's finding does not provide any meaningful answer to the issue framed. The conclusion that the trade marks in dispute were similar is not the same issue raised by the court. It is submitted that the court's improper use of basic legal concepts in framing legal issues resulted in incorrect findings.

The HCT has also tended to fuse distinct legal issues into one. In Sabuni Detergents Limited v Murzah Oil Mils Limited, ${ }^{12}$ the HCT had to consider whether the two trade marks in question were so similar as to cause confusion to consumers. The court adopted a similar approach in Agro-Processing and Allied Products Limited $^{13}$ where trade marks SSB Ngano POA, SSB Unga POA, and SSB Sembe POA were in dispute. ${ }^{14}$

Since similarity addresses a comparison of the marks themselves, while likelihood of confusion addresses the consequence of similarity, each of these concepts is determined using a different legal standard. And where distinct legal issues are fused together, there is a real danger that the court may not determine the issue in its entirety. This is illustrated in the case of Sabuni Detergents, where the court left undetermined the issue whether similarity in marks was likely to cause confusion to consumers. An attempt to consider the former

11 BM Prasad, Mulla, Code of Civil Procedure (17th edn, vol 2, LexisNexis, New Delhi 2007) 722.

12 Commercial Case No 256 of 2001, HCT (Commercial Division), Dar es Salaam (unreported), p 3.

13 n 2, above, p 7.

14 The words 'ngano' and 'sembe' translate in English as 'wheat flour' and 'maize flour', respectively. 
was made in Agro-Processing and Allied Products. However, the court's analysis to this question is not thorough and remains obscure. ${ }^{15}$

HCT case law also demonstrates frequent problems of duplication of legal issues. This is probably because of HCT's misconception of various terminologies. In Sabuni Detergents, for example, the court raised the issue of whether the two trade marks were so similar as to cause confusion to consumers. ${ }^{16}$ At the same time, it framed another issue: was there any infringement of the plaintiff's trade mark? ${ }^{17}$ It is arguable that the second issue is a repetition of the second limb of the first issue unless the defendant raised the defence of authorized use of the brand or any other defence. ${ }^{18}$ In Sabuni Detergents that defence was not raised, so it was unnecessary for the court to consider it. Where there is duplicity, the court wastes time by reconsidering the same legal issues. Also, the court has often found itself engaging in conflicting analysis and opinion regarding the same issues, making its jurisprudence more confusing. This view is supported by the court's findings in Sabuni Detergents, as follows:

Issue 1: whether the trade marks are similar so as to cause confusion to consumers. The judge observed, 'Both gentlemen assessors' views are in the affirmative. I do concur with them. We had the opportunity and privilege of being presented with Exh. P2. It leaves no doubt that the two packages resemble and likely to cause confusion to consumers. I do agree with PW2 that in soap business the packaging has its influence on consumers. Both the plaintiff and PW3 never dealt in retail soap trade, selling bars of soap. Instead, they sold their product (sic) in wholesale or semi wholesale hence their goods were sold in cartons. That already created confusion and as narrated by PW3. Therefore all the foregoing considered, my view is that the two trade marks as depicted in Exh. P2 did cause confusion to consumers.'

Issue 6: Was there then an infringement of the plaintiff's trade mark? The judge said, 'That was the nitty gritty issue of this case. Both gentlemen assessors believe so. So do I. It is uncontravarted (sic) evidence of the plaintiff's case that they (sic) registered their product in June, 2000 and started production of their product soon thereafter. The defendant's product came on market in late 2001. All the above considered it leads me to the inescapable conclusion

15 In his finding, the judge simply concluded that, since the defendant's trade marks were similar to the plaintiff's, the former resulted in confusing of consumers. More analysis of this finding will be considered below.

16 Issue no $1, \mathrm{p} 3, \mathrm{n} 20$, below.

17 ibid, issue no 6 .

18 Similar issues which are sometimes raised by the HCT with regard to an act of trade mark infringement are (i) whether trade marks $\mathrm{X}$ and $\mathrm{Y}$ are that the answer to issue No. 6 is in the affirmative. There was an infringement. The defendant did infringe the FOMA LIMAO trade mark No. 28080 by passing off its product.'

It appears from these two paragraphs that there is a failure by the court to relate the findings of consumer confusion in issue 1 and infringement in issue 6 . As there was no defence of authorized use by the defendant or such other defence as pointed above, the court was supposed to conclude its analyses on infringement in issue 1. Instead, the court misplaced several principles. First, its analysis in issue 1 is based on similarity in goods as opposed to priority of registration in issue 6 . Secondly, although the conclusion in issue 1 seems to relate to those in issue 6 , it was erroneous for the court to find infringement on the basis of priority of registration of dates of the contested trade marks. Thirdly, the HCT also found that the defendant had passed-off the plaintiff's products. Again, this was a misdirection as issue 6 was not framed around passing-off. It was therefore strange for the court to arrive at a conclusion without consideration of it. A plausible approach in framing issues was taken by HCT in Glaxo Group Limited $v$ Agri-Vet Limited. $^{19}$ In that case, the court correctly framed distinct legal issues in their own right. $^{20}$

\section{Assessment of identicalness or similarity in trade marks}

HCT case law demonstrates divergent tests in determining whether two trade marks are identical or similar. These tests are the side-by-side comparison and the global appreciation approach. In the first test, the court displays the contested trade marks side by side and examines and compares their features. In this exercise, the court notes their dominant features, compares and differentiates them. If it is found that the elements of a later trade mark are exactly or almost the same as those in an earlier trade mark, the contested trade marks are identical. However, if the elements of a later trade mark look like those in an earlier trade mark but are not exactly the same, then the two trade marks are similar. In contrast, in the global appreciation approach, the court takes into account all the relevant factors. ${ }^{21}$

so similar as to cause confusion, (ii) whether trade marks $\mathrm{X}$ and $\mathrm{Y}$ are confusingly similar, or (iii) whether there is likelihood of confusion between trade marks $\mathrm{X}$ and $\mathrm{Y}$.

19 Commercial Case No 73 of 2002, HCT (Commercial Division), Dar es Salaam (Unreported), p 2.

20 ibid, issues 1 and 2.

21 The frequently cited case for the global appreciation approach is Sabel $v$ Puma where the European Court of Justice stated: 'The comparison of 
With this test, the court considers the nature of the trade marks involved in a dispute. If, for example, the trade marks involved are only graphics, only visual comparison is relevant. On the other hand, if the conflicting trade marks are capable of being spoken, aural comparison becomes relevant. And, when word trade marks are involved, it is conceptual similarity which is relevant. Sometimes, there may be a combination of words and graphics. In this case, comparison is made between two marks, taking into account particularly of the features which are memorable. The rationale behind the global appreciation test is that the average consumer normally perceives a mark as a whole and does not proceed to analyse its various details.

Early HCT case law indicates that it had always invoked the global appreciation test. The landmark case here is Colgate-Palmolive where the court as per Mapigano, J stated, 'and that what is necessary is to compare the whole of the defendant's mark and get up to see whether there are similarities which go to create or show prospects of confusion and actual deception. ${ }^{22}$ This principle was restated in Tanzania Breweries Ltd $v$ Kenya Breweries $L t d^{23}$ where the court stated that when looking at trade marks in light of complaints of infringement so as to establish similarities, the whole of the plaintiff's mark and the whole of the defendant's mark and not only a particular feature has to be compared no matter how prominent. However, in recent case law, there is a noticeable shift from the global appreciation test to the side-by-side comparison. For example, in Glaxo Group Ltd ${ }^{24}$ counsel for each party sought to analyse the details of the trade marks in dispute. The judge endorsed that approach. However, it is submitted that the side-by-side comparison test fails to reflect consumers' eyes in purchasing product in relevant markets. This is because the products intended to be purchased may not necessarily be found side by side. Moreover, customers who have been purchasing particular products for some time may not spend time comparing and contrasting features of the trade marks in question even when such products are found side by side in relevant markets. In contrast, the global appreciation approach is closer to the consumers' practice in

trade marks should involve a global appreciation of the visual, aural or conceptual similarity of the marks in question, bearing in mind, in particular, their distinctive and dominant components.'

22 n 2, above, p 3.

23 Civil Case No 34 of 1999, HCT at Dar es Salaam (Unreported).

24 n 19, above, pp 2-6.

25 According to the court the fact that the two companies were selling wheat and maize flour was sufficient to find similarity in goods. However, the court did not go further to consider the different ways such wheat and maize flour were packed and put into channel of markets. purchasing products in relevant markets. This is because consumers normally look at the products in overall terms (their colours, structure, etc) rather than concentrating on a specific feature regardless of its prominence.

\section{Identical or similar goods or services Legal issues}

The issue whether goods or services are identical or similar has never been considered in HCT case law. Undoubtedly, this omission has undermined the development of the court's jurisprudence because the degree of similarity between the marks and the goods or services are interdependent in deciding whether there is likelihood of confusion. Accordingly, a lesser degree of similarity between goods or services may be offset by a greater degree of similarity between marks, and vice versa. Yet this symbiotic effect has been ignored by the court making its jurisprudence hollow.

\section{Assessment of identity or similarity in goods or services}

An attempt by the court to compare goods in AgroProcessing and Allied Products was fruitless, since the court formed an opinion that there was no dispute that the plaintiff and defendant were both carrying on similar businesses concerning of maize and wheat flour. ${ }^{25}$ Regrettably, this opinion lacked thorough analysis. Since trade marks are registered so that they can be applied on goods or services to indicate their origin, it is necessary that an assessment as to whether the goods or services are identical or similar is carried out.

Perhaps the starting point for HCT in comparing goods or services could be the International (Nice) Classification system. ${ }^{26}$ However, reference to this classification is sometimes not conclusive in itself because similar goods or services may be classified in different classes while dissimilar goods or services may fall within the same class. This is due to the fact that, under the Nice Classification the range of goods or services covered by each class is very wide. ${ }^{27}$ Specifications must accordingly be read with caution. Given the lim-

\footnotetext{
26 In Tanzania, trade and service marks are registered in respect of particular goods or services in one or more classes of International Classification and any question arising as to which class any goods or services fall is determined by the Registrar: see $s 15$ of the Trade and Service Marks Act, Cap 326 RE 2002.

27 Rhone Poulenc v Reckitt Benkiser WTLR, 18 July 2003 (Colombian Trade Mark Office), cited in J Phillips, Trade Mark Law: A Practical Anatomy (Oxford University Press 2003) 334.
} 
itations of the Nice Classification, courts in different jurisdictions have developed other ways of comparing goods or services. It is now settled that, in comparing goods or services, there is no single decisive test. However, courts have to take into account a broad range of factors. These include, but are not limited to, the nature and characteristics of the goods or services, their origin, their purpose, whether they are usually produced by one and the same manufacturer or distributed by the same wholesale houses, whether they are sold in the same shops over the same counters during the same seasons and to the same class or classes of customers, and whether by those engaged in their manufacture and distribution they are regarded as belonging to the same trade. ${ }^{28}$ This is what HCT has to consider in its analyses.

\section{Likelihood of confusion to consumers Legal issues}

HCT has developed two ways of framing issues on consumer's confusion and trade mark infringement. The first is whether trade marks are sufficiently similar as to cause confusion. The other is whether there is trade mark infringement. The two questions are distinct. Yet, when the defendant raises no defence against infringement, the second question becomes redundant.

\section{Assessment of the likelihood of confusion}

Analysis of the case law developed by HCT shows that the court has scarcely engaged this test in order to assess infringement. Instead, that court has always used similarity in trade marks to determine infringement. In Colgate Palmolive, the plaintiff sued the defendant for trade mark infringement and passing-off of its Colgate products by importing in Tanzania and distributing ABC Dent products whose general make-up, colour marking and appearance of the tube, and package resembled closely the plaintiff's product. In hearing the case, the HCT listed seven issues. Although some of the issues may not be relevant to the present assessment, I reproduce them verbatim to give a broader picture of the court's jurisprudence:

1. Whether $A B C$ Dent is a registered mark and whether the defendants are registered users of the mark in terms of section 31 of Trade and Service Marks Act No 12 of 1986.

28 Jallinek's Application (1946) 63 RPC 59.
2. Whether the defendants are at law concurrent users of an identical or similar mark in terms of section 20(2) of Trade and Service Marks Act No 2 of 1986.

3. Whether the plaintiff by its conduct can be said to have acquiesced of the infringement by allowing the defendant's product to circulate freely before they filed the suit in 1997.

4. Whether the mark and getup used for ABC Dent toothpaste is identical, or confusingly similar, to that used for Colgate toothpaste.

5. Whether or not there is an infringement of the plaintiff's registered trade mark.

6. Whether in a case of trade mark infringement and passing off the plaintiff needs to prove actual confusion or deception.

7. Whether by reason of the defendants conduct, plaintiff has suffered financial loss and is entitled to the reliefs sought.

As can be noted, issues 4 and 5 were poorly framed, since 'confusingly similar' is the test of infringement. Issue 6 could be considered alongside issue 5 because it relates to the manner of proving infringement. While the court omitted to frame an issue on passing-off, at page 13 of the judgment it asserted that the plaintiff had successfully established its claims in both trade mark infringement and passing-off. This was wrong since the court did not determine at all the claims for passing-off. Issues 1, 2, and 3 were properly framed since they were raised in paragraphs 7 and 8 of the defendant's written statement of defence. Issue 7 reflects the relief claimed by the plaintiff.

With respect to the claims of trade mark infringement in issue 5, HCT found that:

... there is no dispute that plaintiff is a registered owner of Colgate toothpaste trade mark. This fact is buttressed by the respective certificate of registration produced as Exh P1. Because of this registration plaintiff's trade mark is protected under section 31 against infringement. The term trade mark infringement as defined in section 32(1) includes use of unregistered trade mark identical or so nearly resembling it as to be likely to deceive or cause confusion in the trade or business. This is exactly what the defendants have done. I am convinced, in answer to the fifth issue, that there is an infringement of the plaintiff's registered trade mark. ${ }^{29}$

In Sabuni Detergents, eight issues were considered by the HCT. Issues 1 and 6 related to trade mark infringement. Issue 1 stated, 'whether the two trade marks are

29 n 2, above, p 11. 
so similar as to cause confusion to consumers'. Issue 6 stated, 'is there any infringement of the plaintiff's trade mark?' Problems with formulation of the two issues have already been considered above.

While the above issues 1 and 6 are almost the same in their effect as there was a defence raised by the defendant as to authorization of use, for example, HCT responded to them differently. With respect to issue 1 , after the court had found that the contested trade marks were similar, it concluded that such similarity created confusion to consumers. ${ }^{30}$ However, in responding affirmatively to issue 6 , the court took into account similarities in the trade marks as well as priority date of plaintiff's registration of trade mark.

Consistently, with the decisions cited above, in Glaxo Group Limited the judge stated:

The similarities in the get-up in exhibits $\mathrm{P} 2$ and $\mathrm{P} 4$ have come up clearly. The provisions of sections 31 and 32 give the plaintiff protection against infringement. The plaintiff is also given the exclusive right to use the trade mark as provided for under section 31 of the Act. The case of Palmolive supra which I fully support expounds what constitutes acts of infringement. The similarities in exhibits P2 and $\mathrm{P} 4$ leave no doubt that the defendant copied and imitated the plaintiff's trade mark and get-up. That amounts to infringement of the plaintiff's registered trade mark COFTA as per sections 31 and 32 of the Act. ${ }^{31}$

Agro-Processing and Allied Products is the most recent judgment to consider trade mark infringement in Tanzania. ${ }^{32}$ Although this case was filed in 2004, judgment was delivered on December 2008. In this case, the court framed the following issue, 'whether the defendants' intended marks SSB Ngano POA, SSB Unga Poa are nearly similar to the plaintiff's mark "POA" likely to deceive or cause confusion hence infringing the plaintiff's trade mark.' In answering this issue, the court held, 'from the above it is clear that the defendant's intended trade marks are similar to the plaintiff's mark as a result it causes confusion. Since the defend-

30 n 12, above, pp 6 and 7.

31 n 19, above, p 10.

32 Between December 2008 and September 2011, only three trade mark cases were filed in the HCT and the Court of Appeal of Tanzania. The first was Said Salim Bakhresa \& Co. Ltd v Agro-Processing and Allied Products Ltd and Registrar of Trade and Service Marks, Civil Appeal No 55 of 2009, Court of Appeal of Tanzania, Dar es Salaam (unreported). This appeal originated from Agro-Processing and Allied Products, Commercial Case No 31 of 2004, HCT. The appeal in Said Salim Bakhresa was struck out in August 2010 by the Court of Appeal of Tanzania for lack of competence as the record of appeal contained a defective decree. The second case is Bata Brands s.a.v.i v Bora Industries Ltd, Commercial Case No 12 of 2010, HCT (Commercial Division), Dar es Salaam. This case has been adjourned indefinitely. The third, IPP Media $v$ Price Bagenda, ant adopted that trade mark it infringes the rights of the plaintiff.'

As can be seen, HCT has at all times considered similarity in trade marks as a conclusive determinant factor for trade mark infringement. However, since similarity as such cannot lead to a finding of trade mark infringement, the court ought to have considered the effect of such similarity on consumers' ability to identify products they intend to purchase from the market. This calls for the engagement of the likelihood of confusion test.

An attempt to use the likelihood of confusion test was made by HCT in Colgate Palmolive (a decision which was principally focused on the preliminary injunction issue).$^{33}$ In finding for the plaintiff, the court held that, in order to determine whether consumers are likely to be confused by similar trade marks, the plaintiff has to establish that a substantial number of customers of average intelligence with imperfect recollection will probably be confused as to the origin of the defendants' goods or the existence (or lack of it) of a connection between the defendants' goods and the goods of the plaintiff. ${ }^{34}$ It is unfortunate that the court's ruling failed to shed sufficient light on the application of this principle. Accordingly, the court ended finding infringement on the basis of mere similarity of trade marks. The most controversial decision in the jurisprudence of the HCT was Tanzania Breweries (a decision which was also principally focused on the issue of preliminary injunctive relief). ${ }^{35}$ There the court rejected the legal test for likelihood of confusion laid down in Colgate Palmolive. In contrast to Colgate Palmolive where the court held that the yardstick for likelihood of confusion is a consumer of average intelligence with imperfect recollection, in Tanzania Breweries, the court held:

in drawing its conclusion, the court has to wear the shoes of a common man, spread the two marks before it and ask itself whether there are resemblances between the two which would make it pick a product which was not intended but the opposite. Applying this test to the plain-

Commercial Case No 20 of 2009, HCT (Commercial Division), Dar es Salaam, is still pending.

33 Makulilo, A.B., 'Trade marks in Tanzania: the prima facie case and interim relief', Journal of Intellectual Property Law \& Practice, 2010, Vol.5, No.8, p.571.

34 The European Court of Justice (ECJ) considered this principle for which trade marks are compared in the leading case of SABEL BV v Puma AG, Rudolf Dassler Sport C-251/95 (1998) ETMR 1. In this case, the ECJ held that the comparison of trade marks should involve a global appreciation of visual, aural, or conceptual similarity of the marks in question bearing in mind, in particular, their distinctive and dominant components.

35 n 33, above. 
tiff's application for temporary injunction, the judge made the following finding, 'I have carefully put myself in the shoes of a common beer consumer and subjected my eyes to the contested trade marks. At the end of this exercise I have concluded that notwithstanding the presence of "Kibo peak" on all brands there is no way the deception to the degree complained of by the Applicant.'

The court rejected the plaintiff's argument that, in deciding whether the resemblance between the marks is capable of confusion or deception in the beer trade, the yardstick used is that of a consumer of beer of average intelligence and with imperfect recollection. ${ }^{36}$ The reasoning of the HCT was that here one deals with an increasingly poor recollection in an ordinary person with the progressive consumption of the product, while the court was suggesting that the recollection of a consumer must be perfect. It likened the plaintiff's argument to putting an insane or drunken person behind the steering wheel of a motor vehicle and expecting him to abide by the traffic rules. The court concluded: 'the person we have in mind here is nobody else but an ordinary person capable of digesting resemblances, similarities and the like. However, in Tanzania Breweries, the HCT failed to analyse systematically the terms common man, common beer consumer, and ordinary person.

\section{Still obscure}

As the preceding HCT case law has demonstrated, the jurisprudence of trade mark infringement in Tanzania remains obscure. The court has failed to apply the likelihood of confusion test in determining trade mark infringement. In all cases, HCT has found infringement on mere similarity in trade marks. In some instances, the court has gone far to consider priority of registration as a criterion for assessing trade mark infringement. An attempt by the court to engage the likelihood of confusion is noticed in Colgate Palmolive and Tanzania Breweries (the likelihood of confusion test was incorrectly brought into application by HCT during consideration of a temporary injunction). The rulings in these two cases do not explicitly explain how to apply the test. 